EDITORIAL

\section{Knowledge commons or economic engine - what's a university for?}

\section{Bryn Williams-Jones}

\section{With closer interactions between academic and commercial entities the role of the university is expanding to also include knowledge transfer}

\ the biomedical and health sciences (as well as other applied sciences), close interactions between academic and commercial entities are now common place. Funds from pharmaceutical and biotechnology companies have helped finance major bioscience projects and research centres, graduate students are receiving training in commercial laboratories, and university scientists are translating their intellectual property' by patenting their research and launching start-up companies. And this is happening with the blessing of universities, who see the commercialisation of research - and the royalties brought in from 'technology transfer' - as part of their new mission.

The result is that no longer are universities simply places of higher learning, where academics are dedicated to teaching and research, traditionally the 'first' and 'second' missions of universities; universities now have a 'third' mission, to engage in knowledge transfer. Governments and researchintensive industries (such as pharma, biotech, IT), are keen to translate university research into marketable products. Facilitated by policies and laws to protect intellectual property rights and aid commercialisation, universities are transforming into 'entrepreneurial' institutions. ${ }^{1}$ University administrators seek to generate new funding streams, while governments see universities as drivers of technology development and economic growth. In such a climate, it should not be surprising that researchers in many disciplines are facing pressure to collaborate with industry and to focus their research on applied areas that can lead to tangible, marketable results. And why should this be a problem?

Universities have, from at least the early $19^{\text {th }}$ century onwards, been places of learning and research predicated on the free flow and open sharing of knowledge. Through the teaching of students, academic discussions, and scholarly publications, a knowledge 'commons' has been created in which new ideas are tested and either accepted or rejected. This Mertonian ideal of science and academia - as a culture sharing norms of universalism, organised scepticism, and disinterestedness - is one to which many if not most academics and universities would subscribe. $^{2}$ In practice, however, academic research often falls short of these ideals; the pursuit of knowledge is never entirely disinterested. There is a long history of effective collaboration between universities and industry, and research is often sponsored by governments, industries, or charities, all of which have particular agendas and interests. Nor is commercialisation limited to scientific research; it also extends to research in other disciplines, as well as to teaching and athletics. ${ }^{3}$ For all that some would decry (or rejoice in) universities being 'Ivory Towers' insulated from the cares of the world, the reality is that academic research is invariably conducted in and responsive to the larger community. ${ }^{45}$ This does not, however, undermine the value of striving for the ideals of academic freedom, objectivity and neutrality; these norms are the foundations of modern universities and continue to be strongly defended. Nor does it mean that universities should reject all commercial involvement and strive to return to some mythical, disinterested state of existence. Yet given the fervour with which some governments and university administrations are embracing the notion of the entrepreneurial university, there is growing concern that the knowledge commons is becoming seriously threatened.

A classic problem with a commons for example, public resources, pasture land, etc - is that as a shared resource which all may access freely, there are strong incentives for individuals to maximise their use at the expense of others, resulting in Hardin's well known 'tragedy of the commons' ${ }^{6}$ This tragedy is resolved by users agreeing to selfregulate, to adhere to a shared moral code as it were, and to constrain usage to ensure equitable benefit and the continued functioning of the commons. Unlike most other kinds of commons, the knowledge commons of academia is not threatened by over-use, but is instead improved through free access, through the sharing and 'consumption' of information. The knowledge commons is endangered, then, when it is 'enclosed' and knowledge becomes 'owned' by individuals or corporations, a situation seen most clearly in the push for greater protection of intellectual property rights. When researchers are encouraged to place economic value on their discoveries and patent them to facilitate innovation, other researchers become less able to access this knowledge or build upon it (despite patent rules that require 'disclosure'). The most blatant examples include patents on DNA, genes, and other biological materials, which block downstream research by radically increasing the transaction costs and making some areas of research not worth investigating. ${ }^{78}$

Industry support for research often comes with the requirement that scientists sign non-disclosure agreements, or agree to delay publication until a patent application is submitted. In its extreme form, this can lead to the suppression of negative results and the 'gagging' of researchers, as in the cases of Nancy Olivieri and David Healy. ${ }^{111}$ Researchers themselves may have real or perceived conflicts of interest - for example, consultation or patient recruitment fees, shares in spin-off companies - that threaten their ability to conduct rigorous, objective and trustworthy scientific research. ${ }^{12}{ }^{13}$ In this context, we begin to see a 'tragedy of the anticommons', a situation in which multiple property rights and conflicting interests lead to the shared resource of knowledge being underused. ${ }^{14}$ New knowledge becomes more difficult to develop, seriously undermining the traditional first (teaching) and second (research) missions of the university, as well as the third mission - the one advocated by governments and industry - of being an engine for economic growth. With universities trying to reap the rewards of their researchers' intellectual property, many industries are finding it difficult to sustain productive relationships with university researchers. In some fields, basic research is being neglected (and with it the possibility for serendipity and unexpected innovation) while in-house technology transfer offices often over-value preliminary discoveries, with the result that 
companies face increasing challenges in translating university-generated knowledge into marketable products and technologies.

Commercial involvement in academia is a reality, and it is not necessarily a bad thing! Universities can and should play a role in economic development and social prosperity, just as they do in debates about politics or social justice. The success of university-industry relations is arguably the result of a healthy knowledge commons in which academics have the freedom to think new ideas that challenge the social, political and intellectual status quo, and to then explore diverse avenues for translating their findings into the wider society and the marketplace. To return then to the question posed in the title of this editorial, "knowledge commons or economic engine?" the simple answer is "both". More complicated, however, is the task of determining what forms of commercial influence are appropriate for enabling universities to develop knowledge that is socially, politically and economically relevant.

$J$ Med Ethics 2005;31:249-250.

doi: 10.1136/jme.2005.012278

Correspondence to: B Williams-Jones, Cardiff Institute of Society, Health and Ethics, School of Social Sciences, University of Cardiff, Cardiff, CF10 3AT; Williams-JonesB@cf.ac.uk

\section{REFERENCES}

1 Etzkowitz H, Webster A, Gebhardt C, et al. The future of the university and the university of the future: Evolution of ivory tower to entrepreneurial paradigm. Research Policy 2000;29:313-330.

2 Webster A. Science, technology and society. New York, NY: Palgrave, 1991.

3 Bok D. Universities in the marketplace: The commercialization of higher education. Princeton: Princeton University Press, 2003.

4 Harding $\mathrm{S}$. Is science multicultural? Postcolonialisms, feminisms, and epistemologies. Bloomington: Indiana University Press, 1998.

5 Nowotny H, Scott P, Gibbons M. Re-thinking science: Knowledge and the public in an age of uncertainty. Cambridge: Polity Press, 2001.
6 Hardin G. The tragedy of the commons. Science 1968;162:1243-1258

7 Caulfield TA, Knoppers BM, Gold ER, et al. Genetic technologies, health care policy and the patent bargain. Clin Genet 2003;63(1):15-18.

8 Eisenberg R. Patenting genome research tools and the law. C R Biol 2003;326:1115-1120.

9 Blumenthal D. Withholding research results in academic life science: Evidence from a national survey of faculty. J Am Med Assoc 1997;277:1224-1228

10 Nathan DG, Weatherall DJ. Academic freedom in clinical research. N Eng J Med 2002;347:1368-1371.

11 Angell M. The truth about the drug companies: How they deceive us and what to do about it. New York: Random House, 2004.

12 Parizeau $\mathrm{M}-\mathrm{H}$. Are the universities and sciences subservient to the economy? A summary and analysis. ISUMA: Canadian Journal of Policy Research 2001;2:133-141.

13 Krimsky S, Rothenberg LS, Stott $P$, et al. Scientific journals and their author's financial interests: $A$ pilot study. In: Caulfield TA, Williams-Jones B, eds. The commercialization of genetics research Ethical, legal, and policy issues. New York, NY: Kluwer Academic/Plenum Publishers, 1999:101-110

14 Heller MA, Eisenberg RS. Can patents deter innovation? The anticommons in biomedical research. Science 1998;280:698-701.

\section{Call for papers}

The Journal of Medical Ethics is planning to publish a number of thematic issues and invites submissions of original or short papers on the following topics:

Deadline 15 June 2005

Neuroethics

Deadline 15 December 2005

Public Health Ethics

Ethical issues is obstetrics and gynaecology

Multidisciplinary research in medical ethics

\section{Deadline 15 June 2006}

Equity and justice in health care

Ethical issues in oncology and palliative care

Teaching ethics to health care students and professionals

If you would like to discuss a possible submission please e-mail Søren Holm at holms@cardiff.ac.uk with your idea. Prior discussion with the editor is not obligatory.

Please state in your submission letter that you would like the paper considered for a thematic issue. 